\title{
FOREST MANAGEMENT CHALLENGES AND OPPORTUNITIES OF TWO-LAYERED BIRCH AND SPRUCE STANDS IN LATVIA
}

\author{
Jānis Vuguls, Guntars Šṇepsts, Zane Lībiete, Pēteris Zālītis \\ Latvia State Forest Research Institute 'Silava', Latvia \\ janis.vuguls@silava.lv
}

\begin{abstract}
Forestry in Latvia in the 20th century was strongly focused on the establishment and management of pure Scots pine and Norway spruce stands trying to avoid any admixture of other tree species. Knowledge on the economic feasibility of the mixed stands' management is still rather poor in Latvia, while at the same time the establishment of mixed stands of Norway spruce and birch species has become an attractive management objective in Finland and Sweden. This paper used the data from the Latvian National Forest inventory to quantify the amount of birch stands with the second layer of spruce, as the first step to justify the development of recommendations for alternative management options in this type of stands. According to the results, there are 121752 ha of birch stands with the second layer of Norway spruce, and most of those are located in Hylocomiosa, Oxalidosa, Myrtillosa mel. and Myrtillosa turf.mel. site types. The mean standing volume of birch stands with Norway spruce understorey was higher than in birch stands with no spruce understorey, and Hylocomiosa, Oxalidosa, Myrtillosa mel. were the most productive site types both in terms of total standing volume and that of the Norway spruce growing in the second layer. Analysed data also revealed that the management of birch stands already now differs strongly in state and private forests, in the latter being more focused on selective fellings. It is possible to develop and test alternative management methods of birch stands with the second layer of Norway spruce to maximise yield and reduce expenses of forest regeneration.
\end{abstract}

Key words: two-layered stands, growth, yield, Picea abies, Betula sp.

\section{Introduction}

Last three centuries of industrialization have raised living standards and developed economies but it has come at a significant cost to the Earth's natural systems - climate, water, air, biodiversity, forests and oceans are all under unprecedented, severe and increasing stress (Schwab, 2018). Under such circumstances, forest ecosystems face multiple challenges due to climate change, invasive species, urbanization, land use change and the interactions between these global change drivers (Pautasso, 2013). The International Union of Forest Research Organizations (IUFRO), leading global network for forest science cooperation in its strategy for 2015 2019 addresses the following five themes for the science collaboration - Forests for People; Forests and Climate Change; Forests and Forest-based Products for Greener Future; Biodiversity, Ecosystem Services and Biological Invasions; Forest, Soil and Water Interactions (IUFRO, 2015). Intensified forest management due to increasing demand for bioenergy and attempts to reduce the pressure on forests of higher environmental value is an important issue to consider, and in the light of this trend questions related to possibilities of increasing forest productivity and stability of forest stands are high on the agenda.

Mixed stands usually display greater stability against biological risks. They are reported to be less susceptible to wind throw (Lüpke \& Spellmann, 1997), butt rot (Piri et al., 1990) and other damage, therefore the establishment of mixed stands is considered as one of the most important adaptation and risk-reduction strategies (Reif et al., 2010). They also provide more heterogeneity, thus securing a higher variety of ecological niches that may be utilized by different organisms, ensuring a positive effect on biodiversity (e.g., Jonsell et al., 1998). Nutrient balance in mixed stands may be more favourable than in monocultures (Sverdrup \& Stjernquist, 2002), and simulations performed by Shanin et al. (2013) indicate that mixed stands may be a viable option to increase forest carbon stock and mitigate climate change. One of them, suggested by simulations and observation in the field experiments, is that a positive mixing effect could result from utilization of different ecological niches (Pretzsch, 2009). Bāders et al. (2018) study reveals that a higher forest structural diversity with spruce admixture has a positive impact against insect damage both on stand and landscape levels.

Forestry in Latvia in the $20^{\text {th }}$ century has largely focused on the establishment and management of pure Scots pine and Norway spruce stands striving to avoid any admixture of other tree species (Bušs, 1985). This kind of forest management was considered to be the most economically efficient because the economic value of birch was low at the time (Zālītis, 2006). Zviedris (1960) stated that transformation of two-layered birch stands with the second storey of Norway spruce into pure spruce stands is not possible by removing only a part of birches in the commercial thinning and Zālītis \& Jansons (2014) support this opinion. At the same time, formation of highly productive pure Norway spruce stand by removing all the birches is not a customary practice in the current forest management.

Knowledge on the economic return from mixed stands is still very poor in Latvia, while at the same time the establishment of mixed stands of 
Representation coefficients for recalculation of results in the respective age classes

Table 1

\begin{tabular}{|c|c|c|c|c|c|c|c|c|c|c|c|c|}
\hline Age group & $1-10$ & $11-20$ & $21-30$ & $31-40$ & $41-50$ & $51-60$ & $61-70$ & $71-80$ & $81-90$ & $91-100$ & $101-110$ & $111-120$ \\
\hline $\begin{array}{l}\text { Correction } \\
\text { coefficient }\end{array}$ & 1.05 & 1.00 & 1.00 & 1.07 & 0.98 & 0.98 & 0.98 & 0.98 & 0.95 & 1.01 & 0.90 & 0.80 \\
\hline
\end{tabular}

Norway spruce and birch has become an attractive management objective in Finland and Sweden. As the future development of roundwood prices is uncertain, a two-species stand has a higher net present value when management decisions are based on predictions of market situation (Lohmander, 1992). Moreover, it may be possible to obtain significantly higher volume of wood in a mixed stand, but the results are very much site- and management regime-dependant. For example, results from the literature suggest that it is possible to reach a total yield of $800 \mathrm{~m}^{3}$ in mixed spruce and birch stands within the same rotation period (Valkonen \& Valsta, 2001). Tham (1988) reported a higher yield from a mixture of birch as shelter trees and spruce in the understorey than in a pure Norway spruce stand. At the same time, Frivold (1982) and Agestam (1985) indicated no higher production in mixed stands than in monocultures of Norway spruce. Very little is known about the economic and ecological effects of a management model where an overstorey of mature birch stand is removed and the second storey of Norway spruce retained for further development.

Considering all the above-mentioned, new approaches are needed to increase the sustainability of forest management on a national, regional and global scale, from the viewpoint of different ecosystem functions and services delivered by forests. However, before recommendations for any management changes may be developed, it is crucial to have information on the stands where the new management scenarios might potentially be applied. Therefore, the aim of the study was to quantify the area and productivity of birch stands with the second layer of Norway spruce that could potentially be converted to spruce stands after the removal of birch overstorey.

\section{Materials and Methods}

Data from the second cycle of the National Forest Inventory (2013-2017) were used to analyse the distribution of birch stands in Latvia. NFI is conducted since 2004; one cycle lasts five years and within each cycle a total of 16157 circular sample plots is measured, recording information on the tree dimensions, damages, stand development as compared to the previous inventory, undergrowth and other parameters. All measurements are performed according to the methodology confirmed by the Latvian Ministry of Agriculture. As silver birch and downy birch are not recorded as separate species in the inventory and occasionally may occur in the same site types, in our analysis we did not separate them but referred to both Betula pendula and Betula pubescens species as 'birch'.

A sub-set of NFI plots was used for the analysis. The following criteria were applied for the sample plot selection: 1 ) only plots in the forest (land category code 10); 2) birch as dominant tree species in the overstorey; 3 ) the size of the sample plot (the sector in the forest) - at least $400 \mathrm{~m}^{2}$. The total number of suitable sample plots for further analysis was 1807 .

For a general analysis of birch forests, the stands were then divided into nine age classes with a step of 10 years $(11-20 ; 21-30 ; 31-40 ; 41-50 ; 51-60 ; 61-70$; $71-80,81-90,91+$ years) excluding 225 sample plots with the stand age 1 to 10 years, as no second storey is usually formed within this age class. Further, sample plots with two-layered birch stands were selected for a more detailed analysis. For that, following criteria were applied: 1 ) in the age classes $11-20 ; 21-30 ; 31$ $40 ; 41-50$ years the second layer of spruce had to be at least $10 \%$ of the total standing volume; 2 ) in the age class 51-60 years - second layer of spruce had to be at least $50 \mathrm{~m}^{3}$ volume; 3 ) in the age class $61-70$ years the second layer of spruce had to be at least $60 \mathrm{~m}^{3}$ volume; 4) in the age class 71-80 years - the second layer of spruce had to be at least $70 \mathrm{~m}^{3}$ volume; 5) in the age classes $81-90$ and $91+$ years the second layer of spruce had to be at least $100 \mathrm{~m}^{3}$ volume.

According to the NFI methodology, each $\mathrm{m}^{2}$ of one $500 \mathrm{~m}^{2}$ large sampling plot represents 0.8 ha. In our study, as we used a sub-set of plots with an area starting from $400 \mathrm{~m}^{2}$, the results were corrected with the respective representation coefficients (Table 1) to maintain the same age structure as in NFI data totals.

Graphical analysis of the available data was carried out to identify and present the main characteristics of birch stands and birch stands with the second storey of Norway spruce. Data analysis was conducted in the MS Excel 2016.

\section{Results and Discussion}

The total area of stands with birch as the dominant tree species in our analysis comprised 770570 ha, and the share of birch stands with Norway spruce in the second layer comprised $16 \%$ of this area (Table 2). The mean standing volume of the stands with spruce second layer was considerably higher in all studied age classes, and, depending on the age class, exceeded the standing 


\section{Productivity and age structure of the birch stands in Latvia}

\begin{tabular}{|c|c|c|c|c|c|c|}
\hline & \multicolumn{3}{|c|}{ Birch stands } & \multicolumn{3}{|c|}{ Birch stands with second layer spruce } \\
\hline $\begin{array}{l}\text { Age class, } \\
\text { years }\end{array}$ & Area, ha & $\begin{array}{l}\text { Standing vol., } \\
\text { million } \mathrm{m}^{3}\end{array}$ & $\begin{array}{c}\text { Average } \\
\text { standing vol., } \\
\mathrm{m}^{3} \mathrm{ha}^{-1}\end{array}$ & Area, ha & $\begin{array}{l}\text { Standing vol., } \\
\text { million } \mathrm{m}^{3}\end{array}$ & $\begin{array}{c}\text { Average } \\
\text { standing vol., } \\
\mathrm{m}^{3} \mathrm{ha}^{-1}\end{array}$ \\
\hline $11-20$ & 151804 & 7.89 & 52 & 13751 & 0.92 & 67 \\
\hline $21-30$ & 78067 & 8.90 & 114 & 15407 & 2.08 & 135 \\
\hline $51-60$ & 133258 & 35.18 & 264 & 24975 & 9.84 & 386 \\
\hline $61-70$ & 113691 & 34.33 & 302 & 20288 & 8.32 & 402 \\
\hline $71-80$ & 61222 & 19.71 & 322 & 12526 & 6.21 & 486 \\
\hline $81-90$ & 29011 & 9.89 & 341 & 3734 & 1.97 & 502 \\
\hline
\end{tabular}

volume of birch stands with no spruce second layer by $15-51 \%$. The largest differences were observed in the age classes $71-80$ years ( $51 \%$ exceedance), $81-90$ years (47\% exceedance) and 51-60 years (46\% exceedance). The smallest differences were observed in 21-50 years old stands, where the mean standing volume of the stands with a spruce second storey was greater than that of the birch stands without Norway spruce by no more than $18 \%$. In the age classes closest to the rotation age (51-60 and 61-70 years) the standing volume of the birch stands with spruce second layer exceeded that of the birch stands without spruce second layer by $46 \%$ and $33 \%$, respectively.

Further analysis of the birch stands with second layer of Norway spruce was conducted in three age groups; the first group included stands aged 11-40 years, the second group - stands aged 41-70 years and the third group - stands aged $71+$ years.

In general, there were 38232 ha birch stands with the second layer of spruce at the age of 11-40 years in Latvia. The total productivity in these stands was by $15-29 \%$ higher than average productivity of the birch stands without Norway spruce second storey. This age group is the one where it is possible to influence the species' composition and productivity the most. There is still opportunity to implement different forest management scenarios in these stands by the choice of method and intensity of the pre-commercial and commercial thinning.

The age group of 41-70 years formed the largest proportion of the birch stands with second layer of spruce - 65745 hectares with 23.44 million $\mathrm{m}^{3}$

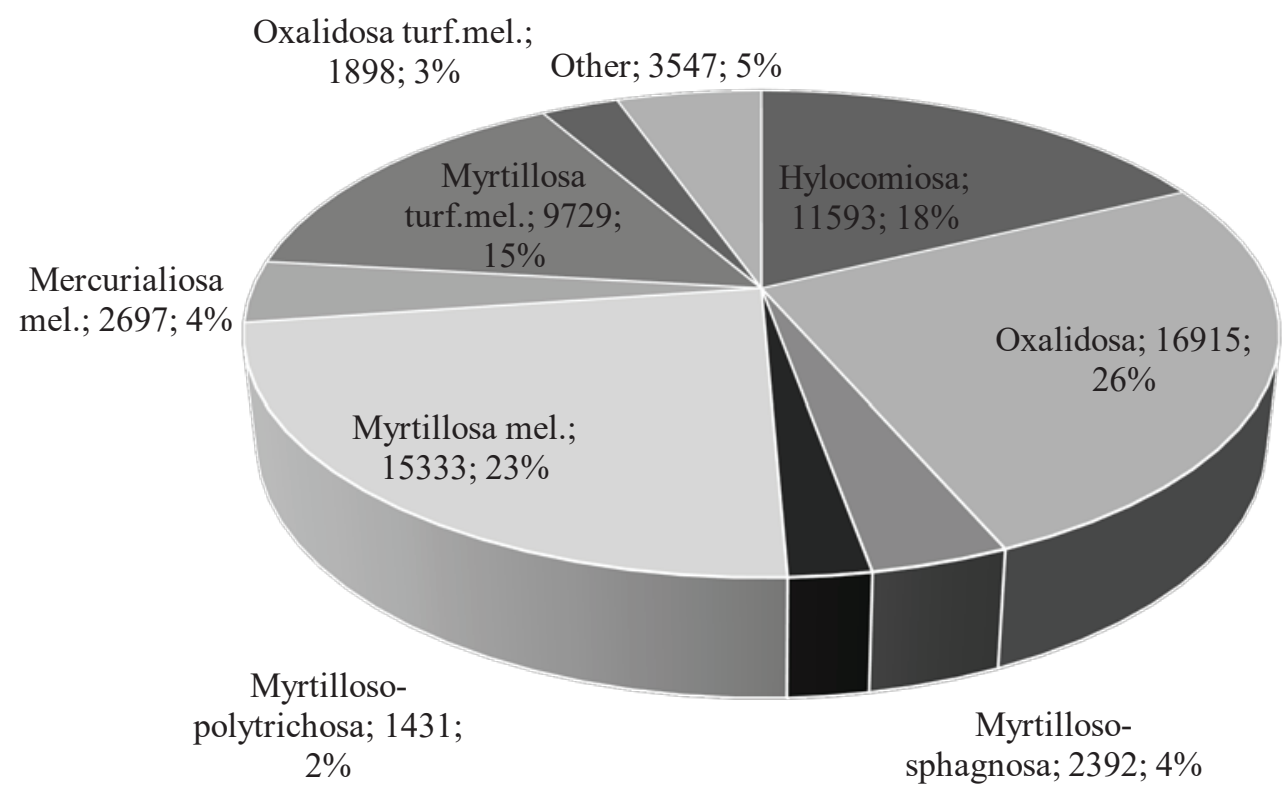

Figure 1. Distribution of 41-70 years old two-layered birch-spruce stands by forest type, area (ha) and share (\%). 
Area and productivity of 71+ years old birch stands with second storey of Norway spruce by site type

\begin{tabular}{|l|l|l|l|l|l|}
\hline \multicolumn{1}{|c|}{ Forest type name } & $\begin{array}{c}\text { Forest type } \\
\text { abbreviation }\end{array}$ & Area, ha & $\begin{array}{c}\text { Standing volume, } \\
\text { million } \mathrm{m}^{3}\end{array}$ & $\begin{array}{c}\text { Average volume, } \\
\mathrm{m}^{3} \mathrm{ha}^{-1}\end{array}$ & $\begin{array}{c}\text { Average volume, } \\
\text { spruce } 2^{\text {nd }} \text { layer, } \\
\mathrm{m}^{3} \mathrm{ha}^{-1}\end{array}$ \\
\hline Hylocomiosa & $\mathrm{Dm}$ & 4880 & 2.62 & 535 & 152 \\
\hline Oxalidosa & $\mathrm{Vr}$ & 5250 & 2.73 & 519 & 112 \\
\hline Aegopodiosa & $\mathrm{Gr}$ & 488 & 0.27 & 565 & 75 \\
\hline Myrtilloso-polytrichosa & $\mathrm{Vrs}$ & 976 & 0.56 & 564 & 75 \\
\hline Dryopteriosa & $\mathrm{Grs}$ & 488 & 0.20 & 409 & 105 \\
\hline Myrtillosa mel. & $\mathrm{As}$ & 2843 & 1.63 & 570 & 159 \\
\hline Mercurialiosa mel. & $\mathrm{Ap}$ & 966 & 0.31 & 317 & 102 \\
\hline Myrtillosa turf.mel. & $\mathrm{Ks}$ & 976 & 0.37 & 374 & 120 \\
\hline Oxalidosa turf.mel. & $\mathrm{Kp}$ & 909 & 0.26 & 287 & 87 \\
\hline & & $\mathbf{1 7 7 7 5}$ & $\mathbf{8 . 9 5}$ & $\mathbf{4 9 2}$ & $\mathbf{1 2 6}$ \\
\hline
\end{tabular}

standing volume. The productivity in this age group was higher than for birch stands on average - by $17 \%$ in the class $41-50$ years, by $46 \%$ in the class 51-60 years and by $33 \%$ in the class $61-70$ years, thus marking these stands as attractive for alternative forest management methods that would include both shortand long-term management perspectives.

The largest share of all stands in this age group were located in the fertile Oxalidosa site type, but a considerable share of 41-70 years old birch stands with Norway spruce second layer was located also in the Myrtillosa mel. site type (mesotrophic sites on drained mineral soils), Hylocomiosa site type (mesotrophic sites on mineral soils) and Myrtillosa turf.mel. site type (mesotrophic sites on drained peat soils) (Figure 1). Thus, these site types stand out as the most productive and perspective for the planning and implementation of alternative management scenarios.

The total area of $71+$ years old birch stands with the second layer of Norway spruce comprised 17775 ha. Similarly to 41-70 years old stands, also within this age group the largest part of birch stands with the second layer of Norway spruce was located in Oxalidosa (30\%), Hylocomiosa (27\%) and Myrtillosa mel. (16\%) site types (Table 3). The average total stand productivity $\left(\mathrm{m}^{3} \mathrm{ha}^{-1}\right)$ was above average in all three site types, and the standing volume of the second layer of Norway spruce exceeded the average value in Hylocomiosa and Myrtillosa mel. site types. Donis et al. (2018) reports that stands on peat soils had significantly more damaged stock in 2005 windstorm in Latvia than stands on mineral soils, therefore we have to be critical considering selective cutting method to remove the birch overstorey in Myrtillosa turf.mel. and Oxalidosa turf.mel. forest types.

Even though the largest share of the birch stands with a second layer of Norway spruce was located in the state forests, the percentage of this type of stands in the private forests was rather high as well - nearly one fifth of the total area of such stands (Figure 2). According to the statistically representative NFI data, the distribution of this type of stands in general was

Other state

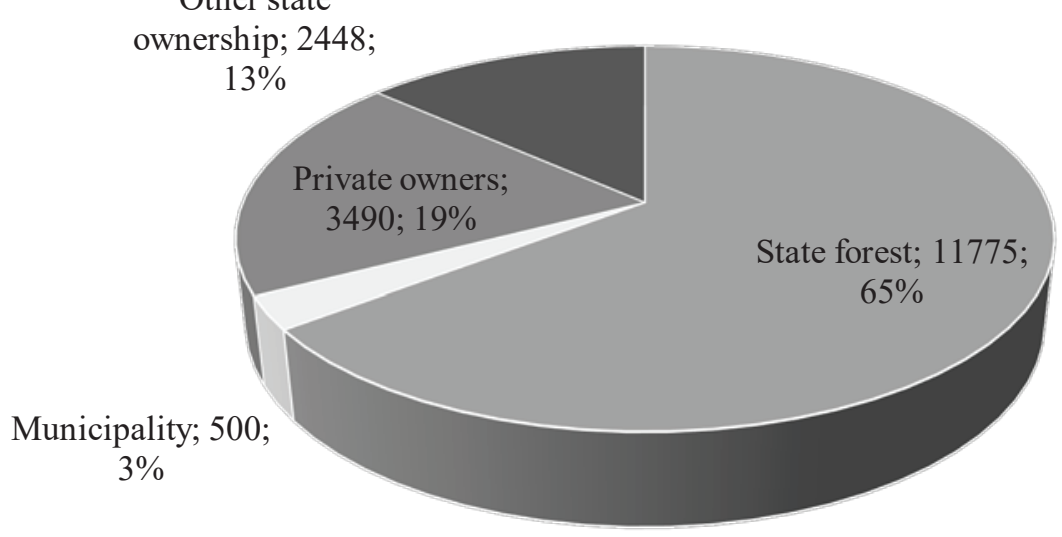

Figure 2. Distribution of 71+ years old two-layered birch-spruce stands by ownership type, area and share. 


\section{Harvested volume and area in birch stands in state and private forests in 2016 and 2017 (Latvia State forest service data)}

\begin{tabular}{|l|c|c|c|c|}
\hline \multirow{2}{*}{ Harvested volume/felled area } & \multicolumn{2}{c|}{ Private } & \multicolumn{2}{c|}{ State } \\
\cline { 2 - 5 } & 2016 & 2017 & 2016 & 2017 \\
\hline Volume clearfelling, million $\mathrm{m}^{3}$ & 1.15 & 1.22 & 1.28 & 1.3 \\
\hline Area clearfelling, ha & 5515 & 5731 & 4819 & 4607 \\
\hline Volume selective felling, million $\mathrm{m}^{3}$ & 0.05 & 0.06 & 0.002 & 0.002 \\
\hline Area selective felling, ha & 1299 & 1269 & 34 & 30 \\
\hline
\end{tabular}

considerably higher than recorded in the State forest register. Similar results were obtained by Zālītis \&Jansons (2014), who concluded that not only the total area of birch stands with the understorey of spruce was higher than expected but also the standing volume of the spruce understorey differed from that recorded in the State Forest register. While, according to the State forest register, the standing volume of Norway spruce growing in the second storey of birch stands was $42 \mathrm{~m}^{3} \mathrm{ha}^{-1}$, actual measurements revealed that it is, in fact, considerably greater and equals $100-$ $120 \mathrm{~m} \mathrm{ha}^{3} \mathrm{ha}^{-1}$ on average. Results from literature suggest that mixed, two-layered birch-spruce stands may have high productivity, and reach even $800 \mathrm{~m}^{3} \mathrm{ha}^{-1}$ in one common rotation, as was demonstrated in the study by Valkonen and Valsta (2001).

In 2017, in the state forests selective fellings in birch stands were performed on an area of only 34 ha, and the total harvested volume was $2164 \mathrm{~m}^{3}$, that is less than $0.01 \%$ from the total harvested volume of birch stands in general. Very similar situation was observed in 2016 when the area and harvested volume of selective fellings in birch stands in the state forests were nearly the same -34 ha and $2167 \mathrm{~m}^{3}$, respectively. At the same time in the private forests this kind of management was implemented on a much larger scale, and the harvested volume in the selective fellings performed in the birch stands was equal to 53910 $\mathrm{m}^{3}$, that is $4 \%$ from the total volume harvested in the final felling in the private forests. In 2017, the share of birch wood harvested in selective felling in the private forests had further increased (Table 4). Thus, it may be concluded that the management strategies in state and private forests dominated by birch differ already now.

This analysis of statistical data has made it obvious that there is a room for alternative approaches, as related to the management of birch stands. Zälītis et al. (2014) hypothesised that if the volume of the second storey of Norway spruce in a two-layered birch spruce stand is $100 \mathrm{~m}^{3} \mathrm{ha}^{-1}$ or greater, it is possible to establish a productive Norway spruce stand in the second generation after the removal of birch overstorey. There are approximately 60 permanent sample plots established and measured in all regions of Latvia where in 2010-2014 this type of management was implemented, leaving also a control plot. These sample plots will be re-measured in the coming years, to test the above-mentioned hypothesis.

\section{Conclusions}

1. Analysis of the Latvian National Forest Inventory data revealed that the area of birch stands with the second layer of Norway spruce equals 121752 ha. Most of these stands are located in Hylocomiosa, Oxalidosa, Myrtillosa mel. and Myrtillosa turf.mel. site types. These stands are also the most productive in terms of standing volume and standing volume of the spruce second layer, therefore, they are potentially interesting for the implementation of alternative management scenarios.

2. The management strategies of birch stands in state and private forests differ already now. In 2016 and 2017 private forest owners applied selective felling method on 2568 ha of birch stands, while only 64 ha were felled with this method in the state forests in the same period.

3. Birch stands with the second layer of Norway spruce of age 41-70 years in Hylocomiosa, Oxalidosa, and Myrtillosa mel. forest types take up area of 43841 ha and are considered as a main target group to apply selective cutting method to.

\section{References}

1. Agestam, E. (1985). A growth simulator for mixed stands of pine, spruce and birch in Sweden. Department of Forest Yield Research, Swedish University of Agricultural Sciences, Garpenberg, Report No. 15, 150 p. (in Swedish with English summary).

2. Bāders, E., Jansons, Ā., Matisons, R., Elferts, D., \& Desaine, I. (2018). Landscape diversity for reduced risk of insect damage: a case study of Spruce bud Scale in Latvia. Forests, Vol. 9, No. 545, article ID DOI: $10.3390 /$ f9090545. 
3. Donis, J., Kitenberga, M., Snepsts, G., Dubrovskis, E., \& Jansons, A. (2018). Factors affecting windstorm damage at the stand level in hemiboreal forests in Latvia: case study of 2005 winter storm. Silva Fennica Vol. 52, No. 4, article ID 10009. DOI: 10.14214/sf.10009.

4. Frivold, L.H. (1982). Stand structure and yield of mixed stands of birch (Betula verrucosa Ehrh., B. pubescens Ehrh.) and spruce (Picea abies (L.) Karst.) in Southeast Norway. Department of Silviculture, Agricultural University of Norway, Ås, Scientific Report No. 18, 108 p. (in Norwegian with English summary).

5. IUFRO (2015) IUFRO'S strategy. Retrieved March 5, 2019, from https://www.iufro.org/discover/strategy/.

6. Jonsell, M., Weslien, J., \& Ehnström, B. (1998). Substrate requirements of red-listed saproxylic invertebrates in Sweden. Biodiversity Conservation 7, 749-764.

7. Lohmander, P. (1992). The multi-species forest stand, stochastic prices and adaptive selective thinning. Systems Analysis Modelling Simulation 9(3), 229-250.

8. Lüpke, B., \& Spellmann, H. (1997) Aspekte der Stabilität und des Wachstums von Mischbestanden aus Fichte und Buche als Grundlage für waldbauliche Entscheidungen (Aspects of stability and growth of Spruce and Beech mixed stands as a basis for silvicultural decisions). Forstarchiv 68 (5), 167-179. (in German with English abstract)

9. Pautasso, M. (2013) Forest ecosystems and global change: The case study of Insubria. Annali di Botanica. 213 (3), 1-29.

10. Piri, T., Korhonen, K., \& Sairanen, A. (1990). Occurrence of Heterobasidion annosum in pure and mixed spruce stands in southern Finland. Scandinavian Journal of Forest Research 5, 113-125.

11. Pretzsch, H. (2009). Forest dynamics, growth and yield. Berlin: Springer-Verlag, 617 p.

12. Reif, A., Brucker, U., Kratzer, R., \& Bauhus, J. (2010). Waldbewirtschaftung in Zeiten des Klimawandels - Synergien und Konfliktpotenziale zwischen Forstwirtschaft und Naturschutz (Forest management in times of climate change - synergies and potential for conflict between forestry and nature conservation). Naturschutz und Landschaftsplanung. 42, 261-266. (in German)

13. Schwab, K. (2018). Shaping the future of the fourth industrial revolution. Switzerland: World Economic Forum, $288 \mathrm{p}$.

14. Shanin, V., Komarov, A., Khoraskina, Y., Bykhovets, S., Linkosalo, T., \& Mäkipää, R. (2013). Carbon turnover in mixed stands: Modelling possible shifts under climate change. Ecological Modelling 251, 232-245.

15. Sverdrup, H., \& Stjernquist, I. (2002). Developing principles and models for sustainable forestry in Sweden. Managing Forest Ecosystems 5, 481 p. Kluwer Academic Publishers, Dordrecht

16. Tham, A. (1988). Yield prediction after heavy thinning of birch in mixed stands of Norway spruce (Picea abies (L.) Karst.) and birch (Betula pendula Roth and Betula pubescens Ehrh.). Department of Forestry Yield Research, Swedish University of Agricultural Sciences, Garpenberg, Report No. 23, 36 p.

17. Tham, A. (1994). Crop plans and yield predictions for Norway spruce (Picea abies (L.) Karst.) and birch (Betula pendula Roth \& Betula pubescens Ehrh.) mixtures. Studia Forestalia 195 (11), 1443-1456.

18. Valkonen, S., \& Valsta, L. (2001). Productivity and economics of mixed two-storied spruce and birch stands in Southern Finland simulated with empirical models. Forest Ecology and Management 140, 133-149.

19. Zālītis, P. (2006). Mežkopības priekšnosacījumi (Preconditions of silviculture). Rīga, et cetera, 218 lpp. (in Latvian)

20. Zālītis, P., \& Jansons, J. (2014). Salikto bērza audžu ražība un to apsaimniekošanas režīms (Productivity and management of two-storey Birch stands). In Jansons, J. (Ed.), Četri mežzinātņu motīvi. Daugavpils, Daugavpils universitātes akadēmiskais apgāds 'Saule', 37-79 lpp. (in Latvian)

21. Zviedris, A. (1960). Egle un eglı mežs Latvijas PSR (Spruce and spruce forests in Latvia SSR). Rīga: Latvijas PSR Zinātṇu Akadēmijas Izdevniecība, 239 lpp. (in Latvian) 